\title{
ISLÂM DAN PEREKONOMIAN ISLÂM DALAM PEMERINTAHAN MODERN
}

\author{
Nashar \\ (D osen Jurusan Tarbiyah STA IN Pamekasan, Jl. Raya Panglegur \\ Km. 04 Pamekasan).
}

\begin{abstract}
A bstrak:
A bstract: the basic of Islamic ekonomy, it is actually different with the basic of Modern Economic System. Because of the view of islam for ekonomy have the characteristic what may be in Modern Economic System. Islam has the guidence based the AI-Qur' an and Hadist and the guidence has the interpretation. The system difference between Islam versus Modern System bears a conclusion : Islamic Ekonomy continuesly and by the all aspects compleyely concerning humanism. Islam has a economic system having the principle of responsibility towards a social community, social living have ability and population economic stimulation. So for the last wise is done by government will always relate with all element of society. There are some economic system is not ruled yet in the sources of Islamic law, as the poroblems of ekonomic system; BUDGET, so it needs to be new ljtihad, therefore, that system always bases on the social service and in line with the guidence of islamic law.
\end{abstract}

\section{Kata Kunci:}

Islâm, ekonomi Islâm, dan pemerintahan.

\section{Pendahuluan}

Terjadinya malapetaka ekonomi yang melanda dunia modern dalam masa seabad terakhir ini seharusnya sudah dapat dijadikan sebagai pelajaran yang berharga bagi umat manusia. Diawali dengan terjadinya malapetaka besar (the great depressions) pada 1930-an, kemudian disusul dengan terjadinya krisis Amerika Latin pada 
dekade 1980-an, malapetaka tersebut harus muncul kembali pada krisis moneter di Asia pada pertengahan 1997, dan terakhir krisis global pada 2009.1

Malapetaka ekonomi tersebut diawali dengan masa-masa inflasi tinggi yang menyakitkan, kemudian perekonomian dunia mengalami suatu resesi yang mendalam dengan laju pengangguran yang belum pernah terjadi sebelumnya. Kondisi itu juga diikuti dengan laju suku bunga riil yang tinggi dan fluktuasi valuta asing yang tidak sehat. Telah banyak solusi yang ditawarkan oleh ekonomi konvensional, akan tetapi krisis demi krisis terus berlanjut. Helmut Schmidt, sebagaimana dikutip Chapra, dalam satu dekade yang lalu pernah mengungkapkan bahwa dunia ekonomi telah memasuki suatu fase ketidakstabilan yang luar biasa dan perjalanan masa depannya benar-benar tidak pasti. ${ }^{2}$

Jika kita melihat terjadinya keberlanjutan malapetaka ekonomi ini, seharusnya kita segera sadar, barangkali ada sesuatu yang salah dalam perjalanan perekonomian yang selama ini ada. Apakah kesalahan itu? Jawabannya akan banyak bergantung kepada tingkat analisis yang digunakan untuk melihat terjadinya masalah-masalah tersebut. Dalam situasi seperti ini, masyarakat Islâm harusnya yang paling berkompeten terhadap penciptaan masyarakat ideal untuk menghindari keterpurukan ekonomi. ebab itu, diperlukan pengerahan segenap tenaga, dimulai dari sumber daya manusianya dan mendayagunakan sumber alamnya. Segalanya demi kesejateraan rakyat.

Realitas objektif yang tidak bisa disangkal, bahwa dunia Islâm juga memiliki SDM yang bagus dan sumber alam yang melimpah, posisi geografis yang strategis dan kondisi ekonomi yang tidak jelek. Harusnya semua ini, sebagai alasan dan Iandasan pencapaian masyarakat impian dan berekonomi yang baik. Prinsipnya, ketertinggalan jangan sampai menjadi identitas umat ini, kemiskinan jangan menjadi simbol pengenal, dan malas jangan karakter khas. Islâm tidak hadir, kecuali untuk melawan itu semua, dan memang

1 Dwi Condro Triono, "Mata Uang Negara Khilafah", M edia Politik dan Dakwah AI Wai' e. N o. 70Tahun VI (Juni 2006), hlm. 15

2 Umar Chapra, Sistem M oneter Islam, terj. Ikhwan A bidin Basri. Jakarta: Gema Insani Press, 2000), hlm. 98 
hal-hal itu juga sebagai lawan semua masyarakat. Sebab itu, masyarakat Islâm harus terpanggil untuk meningkatkan perekonomian dengan sistem yang mandiri serta perpolitikan yang mandiri pula. Maksud peningkatan ini, untuk melewati garis ketertinggalan dan membangun masa depan yang cerah, dengan rujukan ajaran dan metode dasar Islâm.

Kelebihan kita ini, jika tidak kita kembangkan dengan baik, sistematik dan terencana, serta dengan permodalan sains yang memadai, maka bukan tidak mungkin di masa yang tidak terlalu lama, semua kesempatan dan kekuatan yang kita miliki akan sirna dan kita pada akhirnya tidak memiliki apa-apa lagi. Problem perekonomian memang merupakan hal yang paling menghadang umat Islâm. Untuk meciptakan perekonomian yang mapan bagi umat tidak mungkin tanpa adanya planning yang matang, yang digodok oleh para spesialis yang menghasilkan kerangka dasar. Dari sini Ialu diperdayakan segala potensi sumber daya manusia dengan bakat dan keahlian guna mencapai masyarakat yang ideal.

Pemerintah atas nama tanggung jawabnya terhadap warganya, dan dikarenakan otoritasnya atas berbagai instansi, harus berperan serta menyukseskan program tersebut dan harus memiliki konsistensi yang tinggi. Pemerintah harus melegalisasi program ini sebagai undang-undang yang baku agar program kerakyatan ini aman dari perubahan.

Dengan kerangka pemahaman seperti di atas, maka tugas dan tanggung jawab pemerintah semakin luas, dan berarti pula segudang tanggung jawab yang tidak terbatas, berkembang sesuai dengan tuntutan kesejahteraan dan mengacu pada realitas perkembangan dalam dunia modern.

\section{Ekonomi Islâm}

Islâm adalah agama yang diturunkan oleh Allâh swt. untuk manusia melalui perantaraan utusannya, yaitu Nabi Muhammad saw. Sumber-sumber agama Islâm terdapat dalam al-Qur'ân dan As Sunnah. Tujuan utama diturunkannya al-Qur'ân tiada Iain adalah agar dijadikan sebagai petunjuk bagi kehidupan manusia di muka bumi ini. 3 Petunjuk yang diberikan Allâh dalam al-Qur'ân adalah

3 Lihat al-Qur'ân surat al-Baqarah (2): 285. 
petunjuk yang lengkap dan sempurna. Semua masalah kehidupan yang akan dihadapi manusia telah ada penjelasan dan solusinya dalam al-Qur'ân. ${ }^{4}$

Dengan demikian, di dalam Al-Qur'ân dan As Sunnah tentu akan didapati berbagai macam petunjuk Allâh SWT yang dapat diambil oleh manusia untuk menyelesaikan segenap masalahmasalah dalam kehidupannya. Termasuk di dalamnya adalah masalah-masalah ekonomi. Jika kita mau menggali kembali kepada sumber-sumber Al-Qur'ân dan al-Sunnah, maka ketiga pertanyaan yang mendasar di atas akan dapat dijawa satu persatu. Terhadap pertanyaan yang pertama, yaitu: sesungguhnya seluruh harta kekayaan yang ada di dunia itu hak milik siapa? Islâm mempunyai sebuah pandangan yang berbeda sama sekali dengan dua sistem ekonomi yang ada. Islâm memandang bahwa seluruh harta yang ada di dunia ini (bahkan seluruh alam semesta ini) sesungguhnya adalah milik Allâh. Berdasarkan firman Allâh dalam surat al-Nûr: 33, "D an berikanlah kepada mereka sebagian dari harta Allâh yang dikaruniakannya kepadamu" .5

Dari ayat ini dipahami bahwa harta yang dikaruniakan Allâh kepada manusia sesungguhnya merupakan pemberian Allâh yang dikuasakan kepadanya. Hal itu dipertegas dengan mendasarkan pada


hartamu yang A llah telah menjadikan kamu menguasainya." 6

Penguasaan (istikhlaf) ini berlaku umum bagi semua manusia. Semua manusia mempunyai hak pemilikan, tetapi bukan pemilikan yang sebenarnya. Oleh karena itu bagi individu yang ingin memiliki harta tertentu, maka Islâm telah menjelaskan sebab-sebab pemilikan yang boleh (halâl) dan yang tidak boleh (haram) melalui salah satu sebab pemilikan. Islâm telah menggariskan hukum-hukum perolehan individu, seperti hukum bekerja, berburu, menghidupkan tanah yang mati, warisan, hibah, wasiat, dan sebagainya. Ternyata sistem ekonomi Islâm memandang bahwa harta kekayaan yang ada di dunia ini tidak hanya diperuntukkan pada individu untuk dapat dimiliki

4 Lihat al-Qur'ân surat al-Nahl (16): 89.

5Departemen Agama RI, Al-Qur'an dan Terjemahnya (Surabaya: CV. Aisyiah, 1998), hIm. 436.

6lbid. hlm. 509. 
sepenuhnya, tetapi dalam Islâm dikenal dan diatur pula tentang kepemilikan umum, yaitu pemilikan yang berlaku secara bersama bagi semua ummat.

Selain pemilikan umum, sistem ekonomi Islâm juga mengatur tentang kepemilikan negara, seperti setiap Muslim yang meninggal dunia, sedang dia tidak memiliki ahli waris, maka hartanya diberikan kepada Bayt al-M âl, milik negara. Demikian juga contoh yang lain adalah adanya ketentuan tentang kharaj, jizyah, ghanîmah, fa'i, dan sebaganya.

A pabila harta itu telah dikuasai (dimiliki) oleh manusia secara sah, hukum Islâm tidak membiarkan manusia secara bebas memanfaatkan harta tersebut. Islâm telah menjelaskan dan mengatur tentang pemanfaatan harta yang dibolehkan (halâl) dan yang dilarang (haram). Islâm mengharamkan pemanfaatan harta untuk membeli minuman keras, daging babi, menyuap, menyogok, berfoya-foya, dan sebagainya.

Selanjutnya Islâm juga mengatur dan menjelaskan tentang pengembangan harta. Islâm mengharamkan pengembangan harta dengan jalan menipu, membungakan (ribâ) dalam hal pinjammeminjam maupun tukar-menukar, berjudi, dan sebagainya. Islâm membolehkan pengembangan harta dengan jalan jual beli, sewamenyewa, syirkah, musaqah, dan sebagainya.

Adapun ketentuan Islâm terhadap negara, maka Islâm telah menjelaskan bahwa negara mempunyai tugas dan kewajiban untuk melayani kepentingan ummat. Hal itu didasarkan pada salah satu Hadîts Imâm Bukhârî yang diriwayatkan dari Ibnu 'Umar yang mengatakan, Nabi SAW bersabda, "Imam adalah (laksana) penggembala (pelayan). Dan dia akan dimintai pertanggungjawaban terhadap urusan rakyatnya".

Agar negara dapat melaksakan kewajibannya, maka Islâm telah memberi kekuasaan kepada negara untuk mengelola harta kepemilikan umum dan negara dan tidak mengijinkan bagi seorangpun (individu maupun swasta) untuk mengambil dan memanfaatkannya secara liar. Kepemilikan umum, seperti minyak, tambang besi, emas, perak, tembaga, hutan harus dieksplorasi dan dikembangkan dalam rangka mewujudkan kemajuan taraf ekonomi rakyat. Distribusi kekayaan itu diserahkan sepenuhnya kepada kewenangan Imâm (pemimpin negara) dengan melihat dari mana 
sumber pemasukannya (misalnya, harus dibedakan antara zakat, jizyah, kharaj, pemilikan umum, ghanîmah, fa'i, dan sebagainya, maka Islâm telah memberikan ketentuan pengalokasiannya kepada pihakpihak yang berhak menerimanya.

Prinsip umum pendistribusian oleh negara, didasarkan pada firman Allâh surat al-Hayr: 7, "Supaya harta itu jangan hanya beredar di antara orang-orang kaya saja di antara kamu." 7 Maksud dari ayat di atas adalah agar peredaran harta tidak hanya terbatas pada orang-orang kaya saja di negara tersebut. Oleh karena itu, menurut Islâm harta itu seharusnya hanya bisa dimiliki, dimanfaatkan, dikembangkan dan didistribusikan secara sah apabila sesuai dengan ijin dari Allâh sebagai Dzat pemilik hakiki dari harta tersebut.

Secara lebih terperinci dapat dinyatakan bahwa sistem ekonomi Islâm dapat dicakup dalam tiga pilar utama, yaitu: Pertama, kepemilikan (al-milkiyah), yang meliputi kepemilikan individu (almilkiyah al-fardiyah), kepemilikan umum (al-milkiyah al-'âmmah), dan kepemilikan negara (al-milkiyah ad-dawlah). Kedua, pemanfaatan kepemilikan (al-tasharruf fi al-milkiyah), yang meliputi penggunaan harta (infaq al-mâl), yaitu untuk konsumsi dan pengembangan kepemilikan (tanmiyat al-milkiyah), yaitu untuk produksi. Ketiga, distribusi harta kekayaan di tengah-tengah manusia (tauzi'u tsarwah bayna al-nâs), yang meliputi distribusi secara ekonomis, melalui peran individ dan distribusi secara non ekonomis, yaitu melalui peran negara. 8

\section{Peranan Pemerintah dalam Ekonomi Islâm}

Dalam segenap aspek kehidupan bisnis dan transaksi, dunia Islâm mempunyai sistem perekonomian yang berbasiskan nilai-nilai dan prinsip-prinsip syarî'ah yang bersumber dari al-Qur'ân dan Hadîts serta dilengkapi dengan ijmâ' dan qiyâs. Sistem perekonomian Islâm, saat ini lebih dikenal dengan istilah sistem ekonomi syarî'ah.

Sistem ekonomi syarî'ah mempunyai beberapa tujuan, yakni: Pertama, kesejahteraan ekonomi dalam kerangka norma moral Islâm. ${ }^{9}$

7Departemen A gama RI, Al-Q ur'an dan Terjemahnya, hlm. 801.

8 An-Nabhani, Taqyiddin, M embangun Sistem Ekonomi Alternatif Perspektif Islam, Surabaya, Risalah Gusti : 1996.

9 Lihat al-Qur'ân surat al-Baqarah (2): 2 dan 168, al-Mâidah (5): 87-88, al-Jumu'ah (62): 10. 
Kedua, membentuk masyarakat dengan tatanan sosial yang solid, berdasarkan keadilan dan persaudaraan yang universal.10 Ketiga, mencapai distribusi pendapatan dan kekayaan yang adil dan merata.11 Keempat, menciptakan kebebasan individu dalam konteks kesejahteraan sosial.12

Salah satu teori ekonomi syarî'ah yang dikembangkan oleh ahli pemikir Islâm, Ibnu Khaldun, berupa sebuah rumusan berupa kebijaksanaan politik pembangunan, mungkin, dapat diaplikasikan dalam perkembangan IImu Ekonomi Islâm saat ini. Rumusan Ibnu Khaldun tersebut dikenal sebagai "dynamic model of Islâm" atau model dinamika.13 Model dinamika adalah sebuah rumusan yang terdiri dari delapan prinsip kebijaksanaan politik yang terkait dengan prinsip yang lain secara interdisipliner dalam membentuk kekuatan bersama dalam satu lingkaran sehingga awal dan akhir lingkaran tersebut tidak dapat dibedakan, terdiri atas: (1) Kekuatan Pemerintah tidak dapat diwujudkan kecuali dengan implementasi Syarî'ah; (2) syarî'ah tidak dapat dilaksanakan kecuali dengan pemerintahan; (3) pemerintah tidak dapat memperoleh kekuasaan kecuali dari rakyat; (4) masyarakat tidak dapat ditopang kecuali oleh kekayaan; (5) kekayaan tidak dapat diperoleh kecuali dari pembangunan; (6) pembangunan tidak dapat dicapai kecuali melalui keadilan; (7) keadilan merupakan standar yang akan dievaluasi Allâh pada umatNya; (8) pemerintah dibebankan dengan adanya tanggung jawab untuk mewujudkan keadilan.14

Masyarakat dalam sebuah pemerintahan sesuai kodratnya merupakan manusia yang lebih suka hidup secara bersama. Hal ini disebabkan dengan kapasitas individu yang ada, manusia tidak mampu untuk memenuhi kebutuhan pokok guna mempertahankan kehidupan mereka dalam masyarakat. Oleh karena itu, mereka sangat membutuhkan suasana kehidupan yang saling menolong dan bekerjasama. Akan tetapi, mereka tidak dapat hidup berdampingan dan bekerjasama dengan yang lain dalam suasana penuh konflik dan

10 Lihat al-Qur'ân surat al-Hujurât (49): 13, AI-Mâidah (5): 8, al-Syu'arâ (26): 183.

11 Lihat al-Qur'ân surat al-A n'âm (8): 165, al-N ahl (16): 71, al-Zukhruf (43): 32.

12 Lihat al-Qur'ân surat al-Ra'd (13): 36, Luqmân (31): 22.

13 Taqyiddin An-Nabhani, M embangun Sistem Ekonomi Alternatif Perspektif Islam, (Surabaya: Risalah Gusti, 1996), hlm. 268.

$14 \mathrm{Ibid} .$, hlm. 814. 
permusuhan serta ketidakadilan. Untuk itu diperlukan adanya sebuah "rasa kebersamaan" dan "pemerintah" sebagai pengendali kekuasaan untuk mencegah terjadinya konflik dan ketidakadilan guna mempersatukan mereka.

Dalam ajaran welfare state Islâmi, mengupayakan agar setiap orang mengikuti ajaran syarî'ah dalam urusan duniawi mereka merupakan hal yang penting. Negara harus tetap mengawasi semua tingkah laku yang dapat membahayakan pembangunan sosial ekonomi seperti ketidakjujuran, penipuan, dan ketidakadilan sebagai prasyarat kualitas yang dibutuhkan untuk keharmonisan sosial dan pembangunan berdasarkan keadilan. Selain itu, negara harus menjamin pemenuhan hukum dan menghormati hak milik individu serta menanamkan kesadaran kepada seluruh lapisan masyarakat.

A pabila pemerintah melaksanakan peranannya secara efektif, maka akan menjadi sebuah kontribusi positif dalam pembangunan karena kebutuhan masyarakat akan terpenuhi, sehingga mereka akan termotivasi melalui kerja keras yang cermat dan efisien. Namun, jika hal itu tidak terlaksana, maka yang terjadi adalah kehancuran. Sumber daya yang dibutuhkan negara untuk kepentingan itu, diperoleh melalui sistem pajak yang adil dan efisien. Di samping itu, perlu dicermati bahwa apabila, jika pemerintah tidak menerapkan nilai-nilai syarî'ah secara efisien, maka tidak akan ada keadilan. Jika tidak ada keadilan, maka "rasa kebersamaan" tidak akan ada, dan jika tidak ada "rasa kebersamaan", maka tidak akan ada lingkungan yang mendukung terlaksananya implementasi syarî'ah, hukum dan perundang-undangan, pembangunan dan kemakmuran. Ketiadaan semua itu, akan membuat administrasi pemerintah menjadi lemah dan tidak efektif.

Konsep Ibnu Khaldun dalam "M odel Dinamika" menyatakan bahwa negara harus berorientasi kepada kesejahteraan rakyat, memiliki kebijakan anggaran, menghargai hak milik masyarakat, dan menghindari pungutan pajak yang memberatkan. Negara akan mengutamakan pembangunan melalui anggaran yang dihasilkan dari kebijakan yang adil, dan sebaliknya negara akan menghambat pembangunan dengan memperlakuan sistem pajak dan kebijakan yang tidak adil. Negara merupakan suatu pasar terbesar yang dihasilkan dari anggaran negara tersebut untuk kesejahteraan rakyatnya. Untuk itu, negara tidak perlu terlibat secara langsung 
sebagai pelaku pasar, namun harus melakukan hal-hal yang dapat membantu masyarakat menjalankan usaha mereka secara lebih efisien dan mencegah masyarakat untuk melakukan tindakan yang tidak adil secara berlebihan.

Menurut David C. Korten dan Joseph E. Stiglitz, sebagaimana dikutip oleh Zain, pasar yang berhasil mensyaratkan adanya keseimbangan peran antara Pemerintah dan pasar. ${ }^{15}$ Keseimbangan tersebut mungkin berbeda dari satu negara dengan negara lain dan dari waktu ke waktu, juga antara satu sektor dengan sektor lainnya, serta dari satu masalah dengan masalah lain. Tercapainya keseimbangan itu mensyaratkan adanya kejelasan mengenai apa yang harus dilakukan oleh masing-masing dan bagaimana cara melakukannya. Intervensi Pemerintah diperlukan untuk memastikan bahwa kepentingan publik juga terperhatikan. Namun keadaan sebaliknya terjadi pada saat ini. Era ekonomi baru dengan rezim perdagangan bebas, mengharuskan minimalisasi peran Pemerintah suatu negara dalam mengatur perekonomian suatu negara.

Kebijakan-kebijakan Pemerintah yang ikut campur dalam perekonomian dianggap telah menghambat pasar bahkan laju perekonomian. Dengan demikian, deregulasi dianggap sebuah kewajiban bagi rezim perdagangan bebas. Para penyokong rezim perdagangan bebas, mempromosikan, mengurangi regulasi berarti membiarkan kekuatan pasar bekerja. Kekuatan pasar akan menghasilkan lebih banyak efisiensi. Manfaat kekuatan pasar, melalui kompetisi, akan mengalir langsung ke konsumen dan masyarakat luas. Dengan demikian, menurut mereka, perlu dilakukan deregulasideregulasi perekonomian, termasuk sektor-sektor strategis yang mempengaruhi hajat hidup orang banyak.

Deregulasi-deregulasi yang dilakukan secara otomatis mengurangi peran Pemerintah dalam mengatur perekonomian yang dibutuhkan oleh semua golongan. Pihak yang diuntungkan terutama golongan pemilik modal atau eksekutif korporasi global. Para penganjur deregulasi, yakin bahwa semakin ramping Pemerintahan dan semakin rendah tarif pajak akan semakin baik bagi perekonomian. Menurut mereka, uang yang dibelanjakan oleh

\footnotetext{
15Zain, Samih Athif, 1988, Syari'at Islam dalam Perbincangan Ekonomi, Politik dan Sosial sebagai Studi Perbandingan, Hussaini, Bandung, Cet I.., hal. 89.
} 
Pemerintah umumnya terbuang mubazir, sedangkan jika digunakan oleh sektor swasta akan termanfaatkan dengan baik.

Pandangan yang menyetujui peran minimalis pemerintah didasari oleh sebuah ideologi simplistic yang dikenal sebagai "fundamentalisme pasar".16 Secara umum ideologi ini menyatakan bahwa pasar dengan sendirinya stabil dan efisien. Akan tetapi ideologi tersebut tanpa landasan teori ekonomi yang dapat diterima. Pasar yang stabil dan efisien akan terwujud, menurut teori, jika ada informasi yang sempurna, kompetisi sempurna, pasar yang lengkap, dan lainnya yang tidak pernah ada di negara paling maju sekalipun. Kenyataan yang terjadi, adalah, pasar seringkali tidak berjalan baik. Pasar sering menyebabkan terjadinya pengangguran. Pasar tidak bisa dengan sendirinya memberikan jaminan terhadap berbagai risiko penting yang dihadapi perorangan, termasuk risiko menganggur.

Pasar adalah alat untuk meraih tujuan, terutama, standar hidup yang lebih tinggi. Pasar bukanlah tujuan itu sendiri, sehingga langkah-langkah kebijakan yang digencarkan seperti privatisasi dan liberalisasi, janganlah dipandang sebagai tujuan, melainkan sebagai alat. Meskipun tujuan pasar itu sempit (hanya menyangkut kesejahteraan material, bukan nilai-nilai keadilan sosial), pasar bebas seringkali gagal mencapai tujuan-tujuan yang sempit sekalipun. Era 1990-an menunjukkan pasar tidak bisa menjamin stabilitas, sementara pada era 1970-an dan 1980-an, pasar tidak bisa menimbulkan pertumbuhan tinggi, bahkan kemiskinan meningkat sejalan dengan pertumbuhan ekonomi.

Awal-awal millennium, menunjukkan kondisi bahwa pasar bukan hanya tidak mampu menciptakan lapangan kerja yang memadai untuk menampung pendatang baru dalam angkatan kerja. Namun lebih dari yaitu, yakni juga tidak mampu mengimbangi berkurangnya pekerjaan yang ada akibat meningkatnya produktivitas. Pengangguran menunjukkan kegagalan pasar yang paling dramatis sebab menjadikan sumber daya yang paling berharga menjadi mubazir.

\section{Tanggung Jawab Pemerintah dalam Tata Ekonomi M odern}

\footnotetext{
16 Paul Heinz Koesters, Tokoh-tokoh Ekonomi M engubah Dunia; Pemikiran-pemikiran yang M empengaruhi Hidup Kita, (Jakarta: Gramedia, 1987), hlm. 78.
} 
Dalam dunia modern dewasa ini, tanggung jawab pemerintah jelas semakin berat dan komplek di tengah gerak gelombang perekonomian dan sosial masyarakat yang menghinggapi dunia modern. Misalnya, jika pengembangan ekonomi merupakan tantangan pertama bagi negara, menimbang objek ini memang yang diingini mayoritas masyarakat, juga karena mereka telah dengan jerih payah mengupayakannya, maka pemerintah dengan segala instansi di bawahnya, serta perangkat penunjang yang dimilikinya, harus mampu memberikan kontribusi berarti demi penciptaan sistem yang aman dan kemudian menjadi berkembang.

Dalam pencapaian target di atas, diperlukan langkah awal dan faktor penunjang yang harus diadakan lebih dulu. Penunjang itu, misalnya masyarakat produksi harus detraining dan dilatih agar bisa memanfaatkan teknologi modern demi pengembangan SDM-nya, sehingga menambah kualitas hasil produksi. Mereka harus ditraining dengan berbagai rumus baku dan akhirnya mampu mengaplikasikannya pada sistem produksi. Lembaga pemerintah harus menyediakan dana yang diperlukan demi pengandaan produkproduk unggulan.

Apa yang telah kami sampaikan mengenai keharusan menyiapkan perangkat penunjang pembangunan ekonomi adalah hal yang harus. Tanggung jawab pemerintah sekarang tidak terbatas pada keamanan dalam negeri dan pengurus batas-batas N egara. Jika sistem ekonomi modern adalah representasi dari sistem liberal yang dicanangkan di barat di pertengahan abad sembilan belas, maka marilah menengok tragedi sistem liberal yang melumpuhkan negerinegeri berserikat di tahun 1930.

Jika kita semua mencermati negeri-negeri kapitalis dewasa ini, maka kita akan menemukan sistem intervensi yang semakin hari semakin kuat. Intervensi ini dilakukan guna mengatasi kelumpuhan perekonomian yang dahsyat. Mereka sekarang ini tengah menangani kelumpuhan ini secara serius. Kelumpuhan yang terjadi adalah melambungnya berbagai bahan-bahan kebutuhan yang disebabkan persaingan global dengan akibat biaya hidup tinggi. A khirnya negerinegeri ini membuat satu kebijakan taktik bersama guna menyelesaikan masalah di antara mereka. Misalnya mereka membentuk apa yang disebut MEE (Masyarakat Ekonomi Eropa). Tujuan pembentukan ini tak lain adalah demi meyelesaikan problem 
yang semakin parah di daratan eropa. Padahal problem ekonomi mereka yang paling parah, sebenarnya sebagai bawaan sistem yang mereka anut sendiri.

Model intervensi dalam pemerintah Islâm merupakam kiat perlindungan terhadap kesejahteraan individu dan masyarakat banyak di tengah arus gelombang sistem perekonomian modern. ${ }^{17}$ Kapitalis memanjakan ego yang berlebihan dan sosialis memasung hak kemerdekaan individu pemilik. Dalam pandangan Islâm, pemerintah dengan kewajibnya sebagai abdi rakyat, sudah seharusnyalah membantu berbagai hal yang tidak mungkin dilakukan oleh personal. Misalnya penguasaan dan pengurusan terhadap kekayaan alam, tambang atau juga yang terkait dengan investasi modal. Pemerintah juga harus mengawasi dan membantu arus debet dan kredit dan berbagai aktivitas perekonomian serta mengatur secara baik bank-bank sentral.

Disini perlu di catat, jika sistem modern (sosialis, misalnya), dengan pengandaian dianut oleh pemerintahan Islâm dan Ialu pemerintah melakukan intervensi pada gerak perekonomian; mulai dari pengaturan harta milik, arus keuangan dan valuta asing, maka sesungguhnya yang demikian bukan sikap Islâm. Islâm sangat menentang kepemilikan pemerintah pada alat-alat produksi. Sama seperti Islâm sangat menentang suatu sistem di mana rakyatnya hanya diposisikan sebagai alat produksi dan mereka tanpa kreasi yang bebas, sehingga mereka hanya seperti robot.

Sistem Marxisme selain jelas bertentangan dengan fitrah manusia, yang mempunyai rasa memiliki, juga sangat mematikan kiat kreatif, dan dari segi ekonomi, sistem Marxisme jelas tidak menguntungkan. Uji coba di sejumlah Negara membuktikan, Negaranegara itu dalam tempo sepuluh tahun, terlatih-latih dan anggota masyarakatnya miskin tak mampu bergerak sama sekali. Karena hegemoni penguasa terlalu kuat dan otoriter.

\section{Penutup}

Negara dalam Islâm berfungsi sangat sentral fungsinya sebagai ri' ayat sûni al-ummah (pengatur kehidupan umat) agar tenang

\footnotetext{
17 An-Nabhani, Taqyiddin, M embangun Sistem Ekonomi Alternatif Perspektif Islam, (Surabaya: Risalah Gusti, 1996), hlm. 53.
} 
secara politis dan sejahtera secara ekonomi. Jadi tidak sekedar berfungsi minimal (minimalist state) seperti dalam sistem pasar bebas, atau mendominasi perekonomian seperti dalam sistem sosialis. Tidak juga terjerumus terlalu jauh mengatur sehingga memberikan monopoli, proteksi, hak istimewa kepada pengusaha tertentu), atau ekstrim yang lain pemerintah terlalu lemah sehingga tidak dapat berbuat apa-apa menghadapi penyimpangan para pelaku ekonomi, khususnya dari pihak swasta kuat.

Untuk menjaga agar sistem ekonomi Islâm sesuai dengan aturan Islâm, peran dan fungsi negara -untuk mengontrol pelaksanaan sistem ekonomi Islâm- menjadi sangat signifikan. Peran seperti ini hanya mungkin dilakukan bila pemerintah digerakkan oleh para birokrat yang memiliki kepribadian mulia, bersih, yang bekerja benar-benar demi kepentingan kesejahteraan rakyat. Untuk menjaga mental birokrat agar tetap bertindak jujur dan objektif. Islâm melarang keras praktek pemberian suap atau komisi pada pegawai pemerintah. Atas dasar ini pegawai negeri harus mendapat gaji yang layak. Selain kontrol dari negara, harus ada pula pengawasan dari masyarakat. Kontrol masyarakat dan individu agar negara serta masyarkat berjalan sesuai dengan koridor hukum Islam merupakan kewajiban penting bagi kaum Muslim.

\section{D aftar Pustaka:}

Chapra, Umar. Sistem M oneter Islam. terj. Ikhwan Abidin Basri. Jakarta: Gema Insani Press, 2000.

Departemen Agama RI. AI-Qur'an dan Terjemahnya. Surabaya: CV. Aisyiah, 1998.

Koesters, Paul Heinz. Tokoh-tokoh Ekonomi Mengubah Dunia Pemikiran-pemikiran yang Mempengaruhi Hidup Kita. Jakarta: Gramedia, 1987.

Nabhani, Taqyiddin an-. M embangun Sistem Ekonomi Alternatif Perspektif Islam. Surabaya, Risalah Gusti. 1996.

Nashar. Pendidikan Kewirausahaan. Pamekasan: STAIN Pamekasan Press, 2006. 
Rahman, Azalur. D oktrin Ekonomi Islam Jilid II, Yogyakarta: Bentang, 1995.

Sukirno, Sadono. Makro Ekonomi, edisi kedua, Jakarta: Raja Grafindo Persada, 1995.

Triono, Dwi Condro. "Mata Uang Negara Khilafah", M edia Politik dan Dakwah AI Wai'e No. 70 Tahun VI (Juni 2006).

Zain, Samih Athif. Syari'at Islam dalam Perbincangan Ekonomi, Politik dan Sosial sebagai Studi Perbandingan, Bandung: Hussaini, 1988. 